\title{
Insights into Putative Health Implications of Gelam (Melaleuca cajuputi) Honey: Evidence from In-Vivo and In-Vitro Studies
}

\author{
Boon Keng Chan and Hasnah Haron* \\ Nutritional Sciences Programme, School of Healthcare, Faculty of Health Sciences, \\ Universiti Kebangsaan Malaysia, Jalan Raja Muda Abdul Aziz, Kuala Lumpur 50300, Malaysia; \\ nicholas1015@yahoo.com \\ * Correspondence: hasnaharon@ukm.edu.my; Tel.: +603-9289-7457; Fax: +603-2694-7621 \\ Academic Editor: Yu-Jia Chang \\ Received: 19 January 2016; Accepted: 16 February 2016; Published: 24 February 2016
}

\begin{abstract}
Honey has been used as a therapeutic agent since ancient times for health maintenance and the treatment of various ailments. In modern days, researchers reappraised the therapeutic values of honey, such as anti-oxidative, anti-inflammatory, antimicrobial, anti-diabetic, anti-tumor, and wound healing properties. These findings supported its applications in the modern healthcare system as complementary medicine. Gelam honey $(\mathrm{GH})$ is a monofloral Malaysian honey which has been proven to have considerable health benefits. This paper presents a state of the art review on the therapeutic values of GH. A descriptive elucidation is performed to elaborate a wide spectrum of biological activities of GH using evidence from a considerable body of literature. The compositional and physiochemical characteristics of GH have contributed substantially to its putative biological properties. A brief explanation will be presented on GH attributes to familiarize readers with this novel natural health product.
\end{abstract}

Keywords: Gelam honey; anti-oxidative; antimicrobial; anti-inflammatory; anti-diabetic; antitumor; wound healing; physiochemical; compositional

\section{Introduction}

Honey is a natural concentrated sugar mixture with a series of medicinal properties, such as anti-inflammatory [1], wound healing [2], anti-oxidative [3,4], anti-diabetic [5,6], antimicrobial activities [7], and antitumor properties [8,9]. Honey has been used since ancient times, as evidenced by apitherapy as one of the branches in folk medicine for the promotion and maintenance of health as well as treatments of ailments [10]. Honey from different botanical and geographical origins may lead to physicochemical and compositional differences, and ultimately affect their biological activities. Gelam honey (GH) is a Malaysian honey produced by Apis dorsata bees and its main nectar and pollen source is from the flowers of the Melaleuca cajuputi plant, locally known as the Gelam tree. Pollen analysis of $\mathrm{GH}$ revealed the primary predominant pollen species was $M$. cajuputi, which accounts for about $54 \%$ of total pollen frequency [11]. Being a wild monofloral honey, GH is produced widely in the state of Terengganu on the eastern coast of peninsular Malaysia where Gelam trees are abundant [12]. Recently, $\mathrm{GH}$ has received substantial attention from researchers. A body of research has been conducted to characterize the putative health benefits of GH in treatments of various ailments. Within these two decades, GH has come to an exciting stage in healthcare research, in conjunction with the discovery of novel natural therapeutic agents. The present work aims to provide an up-to-date picture of GH utilization in medical research. Comprehensive literature has been summarized and outlined to give 
a better elucidation in order to familiarize readers with pertinent evidence related to novel health implications of GH.

\section{Physicochemical Properties of GH}

Physicochemical attributes of honey are considered to be of great importance, as they reflect the quality of honey. Table 1 shows the physicochemical characteristics of GH based on previous literature [12-15]. The $\mathrm{pH}$ value of GH was similar to other Malaysian honey and was more acidic than Manuka honey from New Zealand [12]. The acidity of honey results from the fermentation of sugar into organic acid, which contributes to honey's flavor and stability against microbial spoilage [16]. The moisture content $(\leqslant 20 \%)$ and hydroxymethylfurfural (HMF) content $(\leqslant 80 \mathrm{mg} / \mathrm{kg}$ ) were within the limit prescribed by the international regulations for honey [17]. Some studies reported moisture contents slightly higher than the permitted range [14,15], which might be ascribed to the harvest season of the honey. Concerning this subject, gamma irradiation was reported as an effective method to reduce moisture content, thus preserving the freshness of honey through reduction of fermentation rate [15].

Table 1. Physiochemical characteristics of Gelam honey (GH).

\begin{tabular}{cc}
\hline Physicochemical Characteristics & Values \\
\hline $\mathrm{pH}$ & $3.55-3.91$ \\
Free acids (meq/kg) & $32.33-50.93$ \\
Lactones (meq/kg) & $5.34-9.00$ \\
Moisture content $(\%)$ & $17.93-20.76$ \\
Electrical conductivity $(\mathrm{mS} / \mathrm{cm})$ & 0.74 \\
Total dissolved solids (ppm) & 368.33 \\
Color intensity / ABS $450(\mathrm{mAU})$ & $500.30-1355.00$ \\
Color characteristic $(\mathrm{mm}$ Pfund) & 122.00, Dark amber \\
HMF content (mg/kg) & $8.52-66.00$ \\
\hline \multicolumn{2}{c}{${ }^{*}$ HMF: Hydroxymethylfurfural. }
\end{tabular}

\section{Chemical Composition of GH}

Honey has a complex chemical composition which consists of more than 200 substances, including sugars, amino acids, vitamins, minerals, polyphenols, and enzymes [18]. Numerous studies have been conducted to quantify the nutritional composition as well as some non-nutritive constituents, such as enzymes, in GH [12,13,19-21]. Table 2 shows the summarized chemical composition of GH.

Table 2. Chemical composition of GH.

\begin{tabular}{ccc}
\hline Chemical Compound & Values & Reference \\
\hline Carbohydrate & & \\
Total sugar content $(\%)$ & $64.93-69.60$ & {$[12,15]$} \\
Reducing sugar $(\%)$ & $62.17-69.16$ & \\
Sucrose $(\%)$ & $0.41-2.77$ & \\
\hline Protein/Amino Acid Content & & {$[12]$} \\
Protein content $(\mathrm{g} / \mathrm{kg})$ & 3.14 & \\
Proline content $(\mathrm{mg} / \mathrm{kg})$ & 261.33 & \\
Mineral Content $(\mathrm{mg} / \mathrm{kg})$ & & \\
Sodium & $17.37-196.84$ & \\
Potassium & $23.04-1363.40$ & \\
Calcium & $21.63-275.77$ & \\
Iron & $2.37-142.37$ & \\
Magnesium & $4.94-31.63$ & \\
Zinc & $4.91-29.23$ & \\
Copper & $0.29-2.21$ & \\
Selenium & 16.20 & \\
\hline
\end{tabular}


Table 2. Cont.

\begin{tabular}{|c|c|c|}
\hline Chemical Compound & Values & Reference \\
\hline Vitamin Content (mg/kg) & & \multirow{7}{*}[15,20,21]{} \\
\hline Thiamin & 13.85 & \\
\hline Riboflavin & 94.21 & \\
\hline Nicotinic acid & 355.38 & \\
\hline Panthotenic acid & 12.93 & \\
\hline Ascorbic acid & $22.90-67.36$ & \\
\hline Vitamin E ( $\mu \mathrm{g} / \mathrm{g})$ & $55.59-70.70$ & \\
\hline \multicolumn{3}{|l|}{ Polyphenol Content } \\
\hline Total phenolic content (TPC) & $\begin{array}{l}\text { 34.30-159.74 mg GAE/100 g; } \\
\text { 8.47-71.51 mg RE/100 g }\end{array}$ & \multirow[t]{2}{*}[12,13,20,22,23]{} \\
\hline Total flavonoid content (TFC) & $\begin{array}{c}1.47-32.89 \mathrm{mg} \mathrm{RE} / 100 \mathrm{~g} ; 3.24-4.30 \mathrm{mg} \\
\mathrm{CE} / 100 \mathrm{~g} ; 46.11 \mathrm{mg} \mathrm{QE} / 100 \mathrm{~g}\end{array}$ & \\
\hline \multicolumn{2}{|l|}{ Phenolic Compounds ( $\mu \mathrm{g} / 100 \mathrm{~g})$} & \multirow{10}{*}{ [22] } \\
\hline Gallic acid & $859.43-876.80$ & \\
\hline Chlorogenic acid & $502.77-528.08$ & \\
\hline Caffeic acid & $428.84-442.01$ & \\
\hline p-coumaric acid & $301.45-308.31$ & \\
\hline Ferulic acid & $356.93-381.37$ & \\
\hline Ellagic acid & $558.78-575.67$ & \\
\hline Quercetin & 1588.90-1594.30 & \\
\hline Hesperetin & $1475.20-1477.78$ & \\
\hline Chrysin & $1498.60-1504.60$ & \\
\hline \multicolumn{2}{|l|}{ Enzymes } & \multirow{3}{*}[21]{} \\
\hline Invertase $(\mathrm{U} / \mathrm{L})^{+}$ & 85.56 & \\
\hline Diastase $(\mathrm{DN})$ * & 0.57 & \\
\hline
\end{tabular}

\section{Antioxidant Activities of GH}

Free radicals have been well documented to have detrimental implications on human health, resulting in a number of pathological conditions such as cancer [24], cardiovascular disease [25], impaired wound healing [26], and gastrointestinal inflammatory diseases [27]. Antioxidants present in natural foods such as honey are recommended in order to scavenge the free radicals. A battery of antioxidant assays is employed to evaluate the antioxidant capacity of a food in the laboratory. However, most studies commonly used DPPH free radical-scavenging activity and ferric reducing antioxidant power (FRAP) assay to determine the antioxidant capacity of GH. A comparative study was conducted to evaluate the antioxidant capacities of GH and coconut honey [28]. The results showed that GH has a free radical scavenging ability of $36.7 \times 10^{-4}$ microequivalent ( $\mu \mathrm{eq}$ ) at a $4 \mathrm{mg} / \mathrm{mL}$ honey extract concentration, where one microequivalent is the ability to reduce one micromole $(\mu \mathrm{M})$ of pro-oxidants. Meanwhile, the total antioxidant power of GH assessed using the FRAP assay was $13.45 \times 10^{2} \mu \mathrm{M} \mathrm{Fe}$ (II) at the honey extract concentration of $4 \mathrm{mg} / \mathrm{ml}$. The antioxidant capacity of GH was significantly $(p<0.001)$ higher than that of coconut honey. The difference might be attributed to the compositional variation between these two honeys.

Khalil et al. reported a DPPH inhibition of $54.64 \%-60.55 \%$ and a FRAP value of $348.33-445.00 \mu \mathrm{M} \cdot \mathrm{Fe}(\mathrm{II}) / \mathrm{kg}$ for $\mathrm{GH}$. In a later study, a radical scavenging activity of approximately $58 \%$ at a concentration of $60 \mathrm{mg} / \mathrm{mL}$ was reported for GH, along with a FRAP value of $325.79 \mu \mathrm{M} \cdot \mathrm{Fe}(\mathrm{II}) / 100 \mathrm{~g}$ [12]. The half maximum inhibitory concentration $\left(\mathrm{IC}_{50}\right)$ of DPPH inhibition appeared to be $14.36 \mathrm{mg} / \mathrm{mL}$ with a FRAP value of $644.28 \mu \mathrm{M} \cdot \mathrm{Fe}(\mathrm{II}) / \mathrm{kg}$ in another study [29]. Hussein et al. [15] revealed the FRAP values of $210.08-1108.90 \mu \mathrm{M} \cdot \mathrm{Fe}(\mathrm{II}) / \mathrm{kg}$ in GH dissolved in distilled water and 188.97-1091.60 $\mu \mathrm{M} \cdot \mathrm{Fe}(\mathrm{II}) / \mathrm{kg}$ 
in GH dissolved in methanol. The DPPH free radical scavenging assay demonstrated GH dissolved in distilled water has an inhibition of $31.46 \%-82.68 \%$ as compared to the lower inhibition observed in methanolic GH (24.37\%-79.26\%). The study also reported that gamma irradiation increased total phenolic compounds and antioxidant activities of GH. Attending to the results from this study, methanol might not be suitable as a solvent for this honey. Methanol serves as an excellent solvent for polyphenols, however, the honey also contains other groups of bioactive constituents that are not well dissolved in methanol. In another study, GH exhibited an $\mathrm{IC}_{50}$ value of $6.68 \mathrm{mg} / \mathrm{mL}$ in a DPPH assay and a FRAP value of $115.61 \mu \mathrm{mol} F($ II) $/ 100 \mathrm{~g}$, indicating that GH has a strong antioxidant capacity, ranked after Tualang honey [23].

Additionally, an AEAC (antioxidant equivalent ascorbic acid content) assay was used to estimate antioxidant content in GH and gave a result of about $317 \mathrm{mg} / \mathrm{kg}$, which was far higher than that of Manuka honey [12]. Several studies reported the significant linear correlation between total phenolic content (TPC) and antioxidant capacities, with r values ranging between 0.789 and 0.965 for the DPPH assay and between 0.761 and 0.990 for the FRAP assay [12,13,22,29], confirming the contributions of phenolic compounds in antioxidant activities. However, other constituents also play important roles in combating free radicals. Ascorbic acid has a significant $(p<0.05)$ correlation with the DPPH assay $(r=0.542)$, whereas proline correlated significantly $(p<0.01)$ with the FRAP assay $(r=0.900)$ [12]. Significant correlations were also observed in protein with both DPPH and FRAP assays, with $r$ values of $0.590(p<0.05)$ and $0.960(p<0.01)$, respectively [12].

Several groups of researchers have attempted to use animal models to confirm the putative anti-oxidative activities of GH. In 2011, Yao et al. [30] conducted a study to evaluate the anti-oxidative effects of GH in young and middle-aged rats. The results indicated that GH supplementation reduced DNA damage and plasma malondialdehyde (MDA). The decrease of MDA level was in a dose-dependent manner. GH supplementation modulated antioxidant enzyme activities in erythrocytes by increasing gluthathione peroxidase (GPx) activity and reducing catalase (CAT) activity in both young and middle-aged groups. The reduction of GPx and CAT activities were observed in the liver in both age groups, whilst SOD (superoxide dismutase) was decreased significantly $(p<0.05)$ in the young aged group only. Makpol et al. [31] also reported that pre-treatment with GH at $6 \mathrm{mg} / \mathrm{ml}$ reduced the DNA damage in gamma-irradiated human diploid fibroblasts (HDFs), but GH treatment given during and post-irradiation increased the level of DNA damage as compared to untreated control. Cell survival rate of HDFs decreased with increasing dose of gamma-ray exposure, and treatment with $\mathrm{GH}$ at pre- and during-radiation increased the cell survival rate. This indicates that $\mathrm{GH}$ acts as a protective agent in gamma-irradiated HDFs. Similarly, Sahhugi and coworkers [32] reported that GH supplementation reduced DNA damage and plasma MDA levels in young rats but not in aged rats when compared to their respective control group. GH supplementation also significantly increased cardiac superoxide dismutase activity in young rats and cardiac CAT activity in both young and aged rats. Meanwhile, there were no changes in erythrocyte SOD and GPx activity in both age groups as compared to their control counterparts, but CAT activity increased in young rats $(p<0.05)$.

Batumalaie et al. [33] used a different model to examine the antioxidant effects of GH. Hamster pancreatic cell lines (HIT-T15) were used and cultured in both normal and hyperglycemic conditions. Exposure of HIT-T15 cells to GH extract and its flavonoids (chrysin, luteolin, and quercetin) showed maximum cell viability at a concentration of $80 \mu \mathrm{g} / \mathrm{mL}$ and $80 \mu \mathrm{M}$, respectively. In hyperglycemic conditions, pretreatment of GH extract and its flavonoids increased cell viability significantly as compared to the cells cultured with glucose alone $(p<0.05)$. In a dose-dependent manner, the ROS generated in the presence of glucose was inhibited by GH extract and flavonoids. Pretreatment of GH extracts and flavonoids in individual cells under normal conditions has reduced the ROS activity in single cells in a dose-dependent manner. Lipid peroxidation was assayed using measurements of thiobarbituric acid-reactive substance (TBARS) and MDA. The results revealed that GH extract and its flavonoids reduced MDA production in the cells cultured in hyperglycemic circumstances. The F2 isoprostane production was measured to investigate the effect of $\mathrm{GH}$ extract and its flavonoids on 
the damage of free radicals induced by glucose in HIT-T15 cells. Unsurprisingly, pretreatment with GH extract and its flavonoids significantly reduced the production of F2 isoprostanes $(p<0.05)$ as compared to cells cultured in glucose alone. The researchers further examined the activities of GH and its bioactive constituents on insulin content. Pretreatment of GH honey and its flavonoids showed a significant $(p<0.05)$ elevation of insulin content as compared to the cells cultured in glucose alone.

\section{Anti-Inflammatory Activities of GH}

Inflammation is a complex physiological reaction of the body against infections, irritations, injuries, and cell damage, where it has vital roles in both innate and adaptive immunity [34,35]. Inflammation participates in a wide spectrum of chronic and degenerative diseases, such as rheumatoid arthritis, asthma, neurodegenerative diseases, inflammatory bowel disease, and cancer [36,37]. A series of pro-inflammatory cytokines are released during inflammation, namely interleukin 6 (IL-6), IL-12, tumor necrosis factor (TNF), interferon (IFN-Y), cyclooxygenase-2 (COX-2) and inducible nitric oxide synthase (iNOS), which initiate and amplify the inflammatory process [37-39]. Nuclear factor kappa B $(\mathrm{NF}-\mathrm{kB})$ is a transcription factor regulating the expression of various genes encoding pro-inflammatory mediators [40,41].

Compelling evidence from in vivo and in vitro studies have supported the anti-inflammatory property of GH. Kassim et al. [42] evaluated the inhibitory activity of GH on inflammatory mediators. GH and its extracts (methanol and ethyl acetate extracts) were used in the study. In a non-immune inflammatory and nociceptive model, rats' paws were induced with carrageenan. Injection of lipopolysaccharide (LPS) was given to rats to study the anti-inflammatory effects of honey in an immune inflammatory model. Edema in the paw was measured using plethysmometer, and the results showed that GH and its extracts significantly reduced edema in both models $(p<0.05)$. The extracts (both methanol and ethyl acetate extracts) showed higher inhibition of edema in both models as compared with honey. This indicated that phenolic compounds play an important role in the inhibition of edema. The results showed that GH and its extracts also significantly reduced the pain indicated through the measurements of infrared withdrawal latency. The LPS groups had higher concentrations of nitric oxide $(\mathrm{NO})$ and prostaglandin $\left(\mathrm{PGE}_{2}\right)$ in exudates of paw tissues as compared with the carrageenan groups, exceptionally for the indomethacin groups which showed approximately the same quantity of inflammatory mediators. GH and its extracts significantly inhibited NO and $\mathrm{PGE}_{2}(p<0.05)$.

Hussein et al. [43] conducted another study to examine the inhibition of GH against inflammation. Pretreatment with GH for 1 or 7 days, at a concentration of either 1 or $2 \mathrm{~g} / \mathrm{kg}$ body weight, reduced the formation of paw edema significantly in a dose-dependent manner $(p<0.05)$. Plasma NO level increased in those inflammation-induced rats. However, oral feeding of GH at either dose significantly reduced the NO levels in rats with carrageenan-induced inflammation. The effect of $2 \mathrm{~g} / \mathrm{kg}$ of body weight of honey administration was similar to that of the NSAID Indomethacin given at a dose of $10 \mathrm{mg} / \mathrm{kg}$ of body weight. In addition, GH significantly inhibited $\mathrm{PGE}_{2}$ production in both 1- and 7-day models. Plasma TNF- $\alpha$ and IL- 6 were determined using ELISA, showing a decrease in the production of plasma TNF- $\alpha$ and IL- 6 . The effect of pretreatment at $2 \mathrm{~g} / \mathrm{kg}$ body weight for 7 days was comparable to the effect of the NSAID Indomethacin. Real-time polymerase chain reaction (RT-PCR) and Western blot analysis were performed to evaluate the effect of GH on the expression of inflammatory-related enzymes (iNOS and COX-2), and pro-inflammatory cytokines (TNF- $\alpha$ and IL-6) genes and proteins in paw edema. GH at either dose significantly suppressed the gene expression of pro-inflammatory mediators $(p<0.05)$. Western blot analysis demonstrated that GH inhibited the protein expression of iNOS, COX-2, IL-6, and TNF- $\alpha$ in rat paw tissue in a dose-dependent manner.

The same group of authors has undertaken a different study to investigate the anti-inflammatory mechanism of GH in carrageenan-induced rat paw inflammation via the NF-kB pathway [44], the same doses ( 1 or $2 \mathrm{~g} / \mathrm{kg}$ body weight) and duration (1 and 7 days) were used. The expression of NF- $\mathrm{KB}$ (p65 and p50) and inhibitors of $\kappa B(I \kappa B \alpha)$ genes in inflamed rat paws were significantly attenuated by 
pretreatment with GH in all doses and duration, and a greater down-regulating effect was observed in pretreatment with $2 \mathrm{~g} / \mathrm{kg}$ of body weight of GH for 7 days-the effect was similar to that of Indomethacin. The cytoplasmic level of p65 and p50 increased significantly by the pre-treatment with $\mathrm{GH}$, meanwhile the nuclear level of p65 and p50 decreased significantly with GH pre-treatment. Carrageenan injection induced the cytoplasmic degradation of the I $\mathrm{B} B \beta$ protein. The cytoplasmic level of IKB $\beta$ significantly increased with pretreatment with GH. Histological analysis showed the infiltration of inflammatory cells was significantly decreased with treatment of GH. Immunohistochemistry assay revealed a significant reduction of TNF- $\alpha$ and COX-2 protein expression in the carrageenan-induced inflammation group.

To examine the anti-inflammatory effect of the intravenous injection of GH, Kassim et al. [45] performed a separate investigation using rats with LPS-induced endotoxemia. The authors reported a significant reduction in TNF- $\alpha$ levels after $4 \mathrm{~h}$ of GH treatment in rats injected with LPS. However, the effect was short-lived and was no longer observable at $24 \mathrm{~h}$ after treatment. It was noteworthy that honey showed strong inhibitory activity against IL-1 $\beta$ and IL-10 in the honey-treated group; there were significant differences in the levels of these two cytokines between the honey-treated groups and control group at $4 \mathrm{~h}$ and $24 \mathrm{~h}$ following treatment. Following GH treatment, IL-6 levels remained unchanged and similar to that of control group, while serum high motility group box 1 (HMGB1) protein levels decreased only at $24 \mathrm{~h}$. A significant reduction in NO production was induced by GH at $4 \mathrm{~h}$, and to a lesser extent at $24 \mathrm{~h}$. Besides, GH was a potent inducer of hemeoxygenase- 1 (HO-1), where significant differences between the honey-treated groups and the control group were evident at $4 \mathrm{~h}$ and at $24 \mathrm{~h}$. The effort to explore the anti-inflammatory effects of GH was continued with a recent research work by Aziz et al. [46]. In a periodontitis-induced Sprague-Dawley rat model, GH was able to reduce $21.26 \%$ of plasma IL- $1 \beta$ and $81.27 \%$ of tissue IL- $1 \beta$, suggesting the potential of GH in periodontal disease treatment.

An anti-inflammation mechanism of GH was proposed at the molecular level (Figure 1) [44]. GH might inhibit inflammation via suppression of the NF- $\mathrm{kB}$ pathway. The incoming signal pathway which activates the inhibitor of kappa $\beta$ kinase (IKK) complex is blocked, disrupting phosphorylation, ubiquitination, and degradation of IKB proteins. This subsequently prevents the translocation of NF- $\mathrm{KB}$ dimers (p65 and p50) into the nucleus, and ultimately reduces the expression of inflammatory mediators such as iNOS, COX-2, TNF- $\alpha$, and IL-6, as well as production of NO and PGE 2 .

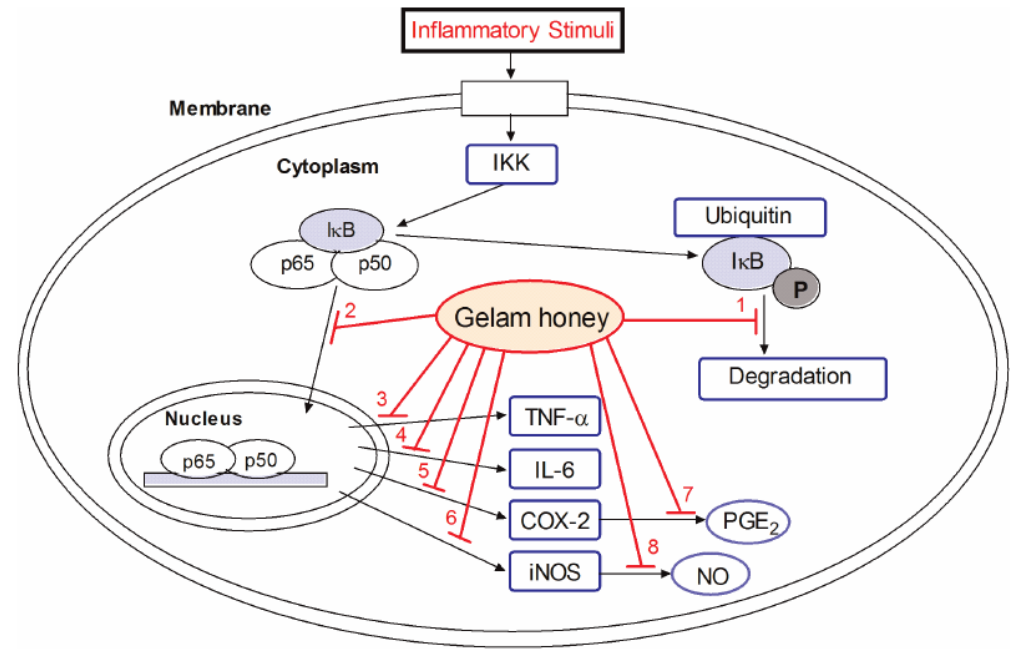

Figure 1. Proposed mechanism by which GH exerts inhibition on inflammation. GH inhibits (1) the degradation of inhibitors of $\kappa B(I \kappa B \alpha)$ that causes (2) nuclear translocation of Nuclear Factor $\kappa B$ (NF- $\mathrm{kB}$ ) dimer (p50 and p65), resulting in the reduced expression of inflammatory mediators, including (3) Tumor Necrosis Factor alpha (TNF- $\alpha$ ); (4) Interleukin 6 (IL-6); (5) Cyclooxygenase 2 (COX-2); and (6) inducible nitric oxide synthase (iNOS). The down-regulation of COX-2 and iNOS expressions decrease the productions of (7) Prostaglandin ( $\mathrm{PGE}_{2}$ ) and (8) Nitric Oxide (NO) [44]. 


\section{Antimicrobial Properties of GH}

Honey has been identified as a natural antimicrobial agent. This biological activity is attributed to its unique composition, containing both bee-origin glucose oxidase and non-peroxide constituents such as phenolic compounds, flavonoids, antibacterial peptides, methylglyoxal, methyl syringate, antibiotic-like derivatives, and other trace components [47-49]. Several studies have been conducted to screen the antibacterial properties of GH against bacterial strains.

In 2013, Zainol et al. [50] conducted an in vitro study to assay the antibacterial activity of GH along with few other Malaysian honeys. Comparatively, GH showed the lowest minimum inhibitory concentration (MIC) and minimum bactericidal concentration (MBC) values against all bacterial isolates in the broth dilution method. The MIC and MBC values for GH were $5 \%-15 \%(w / v)$ and $6.25 \%-15 \%(w / v)$, respectively. The agar well diffusion assay revealed that GH had a high antibacterial activity against Bacillus cereus with equivalent phenol concentration (EPC) measurements of $23.04 \%$ $(w / v)$ in total activity and $22.31 \%(w / v)$ in non-peroxide activity. GH has also been reported to have excellent antibacterial activities in a recent study by $\mathrm{Ng}$ et al. [51]. GH was superior to Tualang and Durian honeys in terms of inhibitory activities against human pathogenic bacteria. GH exerted its inhibition to most of the tested strains from concentration of $40 \%$ undiluted honey. It was effective against Klebsiella pneumonia, Staphylococcus aureus, S. epidermidis, vancomycin-resistant enterococci (VRE) (Enterococcus faecalis and E. faecium), Escherichia coli, and Salmonella enterica serovar Typhimurium. The MIC values were in the range of $125-1000 \mathrm{mg} / \mathrm{mL}$, while MBC ranged $125-2000 \mathrm{mg} / \mathrm{mL}$. The potency of the antibacterial properties of the honey was outlined as GH > Tualang honey > Durian honey. Meanwhile, the main author worked with other researchers to screen the effects of honey on Enterococcus spp. biofilm [52]. Enterococcus spp. biofilms formed on medical devices such as artificial hip prostheses, prosthetic heart valves, central venous catheters, intrauterine devices, and urinary catheters was a devastating medical problem [53]. Manuka honey was more effective in reducing established biofilm biomass as compared to GH. Despite this, GH was comparable to Manuka honey in terms of preventing biofilm formation of Enterococcus spp. GH has been reported to inhibit bacterial growth completely at $1 \mathrm{~g} / \mathrm{mL}$ and exhibited the greatest reduction of biofilm biomass at a concentration of $0.5 \mathrm{~g} / \mathrm{mL}$. A comparative study was conducted to investigate the antibacterial activity of GH and Coconut honey against four selected bacterial species, namely E. coli, S. aureus, Methicillin-Resistant S. aureus, and Methicillin-sensitive S. aureus [54]. The growth of all bacterial strains was partially inhibited by the phenolic extract of GH at $1.3 \mathrm{mg} / \mathrm{ml}$ and completely inhibited at $>1.95 \mathrm{mg} / \mathrm{mL}$ in a broth dilution assay. The disc diffusion assay revealed that GH extract inhibited all tested strains, starting from the lowest concentration, $0.65 \mathrm{mg}$, and the inhibition was in a dose-dependent manner. Both assays showed that GH had a more pronounced anti-bacterial activity than Coconut honey.

\section{Anti-Proliferative and Chemo-Preventive Properties of GH}

Cancerous cells lack of the ability to maintain a balance between apoptosis and cell renewal, in which the cells are continuously dividing, resulting in cellular and organ dysfunction. Researchers have attempted to discover novel natural products possessing anti-proliferative properties. A study conducted by Jubri et al. [55] aimed to study the anti-proliferative activity and apoptosis induction of GH on a liver cancer cell line (HepG2) and a normal liver cell line (WRL-68). MTS assay revealed the $\mathrm{IC}_{50}$ values of $\mathrm{GH}$ towards HepG2 and WRL-68 cells were $25 \%$ and $70 \%$, respectively. In a bromodeoxyuridine (BrdU) assay, GH was found to reduce the proliferation of HepG2 at concentrations of $3 \%$ to $70 \%$. The morphological analysis showed the reduction in cell size in GH-treated HepG2 cells. The findings substantiated the potential efficacy of GH as an anti-proliferative agent through apoptosis induction.

In a similar manner, Wen et al. [56] performed a study to observe the anti-proliferative effect of GH on the HT29 colon cancer cell line. Comparatively, the results indicated that GH was more potent than Nenas honey in suppressing the growth of colon cancer cells, with a lower $\mathrm{IC}_{50}$ of $39.0 \mathrm{mg} / \mathrm{mL}$. The results showed that honey has a similar effect to the anti-inflammatory drug indomethacin in 
reducing $\mathrm{PGE}_{2}$ production by inflammation-induced cells. The findings suggested that $\mathrm{GH}$ is capable of suppressing the growth of HT29 colon cancer cells by inducing apoptosis and retarding inflammation. In another study [57], GH showed an anti-proliferative effect and induced cell death in all tested cancer cell lines (breast adenocarcinoma, MCF-7; human colorectal carcinoma, HCT-116; HepG2, and human alveolar basal epithelial adenocarcinoma, A549). Maximum cytotoxic effect was at $72 \mathrm{~h}$ on HCT116, with $\mathrm{IC}_{50}$ of $3.98 \%(v / v)$ followed by MCF-7 $\left(\mathrm{IC}_{50}=6.31 \%\right)$.

In a very recent study, Tahir et al. [58] evaluated the synergistic effect of crude ginger extract and $\mathrm{GH}$ as potential chemo-preventive agents against HT29 cells. In the MTS assay, the $\mathrm{IC}_{50}$ of ginger and GH were $5.2 \mathrm{mg} / \mathrm{mL}$ and $80 \mathrm{mg} / \mathrm{mL}$, respectively. The synergistic action of these two dietary agents was well depicted when the $\mathrm{IC}_{50}$ values of the combination treatment were lower for both ginger $(3 \mathrm{mg} / \mathrm{mL})$ and $\mathrm{GH}(27 \mathrm{mg} / \mathrm{mL})$ with a combination index of $<1$. ELISA and RT-PCR were conducted, and the results revealed that cell death induced by the combined treatment was associated with the up-regulation of caspase 9 and $\mathrm{I} \kappa \mathrm{B} \alpha$ gene expression, which stimulates early apoptosis. The expression of KRAS, ERK, AKT, Bcl- $x \mathrm{~L}$, and NF- $\kappa B$ (p65) genes was down-regulated by the combined treatment. The results suggested the combined treatment as a chemo-preventive agent to induce apoptosis of colon cancer cell. In another study [59], the chemo-preventive properties of the combined treatment were further explored using mTOR, Wnt $/ \beta$-catenin, and apoptosis signaling pathways. The gene expressions of AKT, mTOR, Raptor, Rictor, $\beta$-catenin, GSK3 $\beta$, TCF4, and cyclin D1 were down-regulated, whilst the gene expressions of cytochrome $C$ and caspase 3 were up-regulated by the combined treatment. Attending to these results, the combination of $\mathrm{GH}$ and ginger might serve as a potential chemo-preventive agent by inhibiting mTOR and Wnt/ $\beta$-catenin signaling pathways as well as the apoptosis induction pathway.

\section{Wound Healing Properties of GH}

Wound healing is a cascade of cellular and biochemical events, comprising three stages, namely inflammation, proliferation, and maturation [60]. Honey is one of the oldest and most enduring natural therapeutic agents in wound management, and can be administered topically or systematically and used alone or in combination with other substances [61,62]. The effort to explore the wound healing potential of GH was initiated by Aljadi et al. [60]. Biophysical and biochemical changes were observed in excision wounds of Sprague-Dawley rats. Quantitative biochemical analyses showed that a combination of topical and oral honey administration had a higher content of DNA, collagen, uronic acid, hexosamine, and serum albumin as compared to wounds treated with topical administration alone and control group. These measurements were consistent with the rate of wound contraction and epithelialization, in which the combined treatment group showed an accelerated wound healing. Rozaini and coworkers [63] evaluated tensile strength on burn wound healing treated with honeys in male Sprague-Dawley rats. Comparatively, the GH-treated group showed a higher value of tensile strength at day $3,14,21$, and 28 days post injury as compared with the control group, but the value was lower than that of the Nenas honey-treated group. The same group of authors tested the wound healing effects of honeys using histological evaluation [64]. Inflammatory cells, especially neutrophils, were significantly lower, while proliferative cells (fibroblasts and endothelial) were significantly higher in GH-treated wounds as compared to control group $(p<0.05)$. These findings suggested that the honey accelerates dermal repair in wound healing. Another study [65] reported that topical application of GH significantly stimulated the rate of burn wound healing by increasing the rate of wound contraction. The effects were similar to Manuka honey-treated wounds.

Yusof and his colleagues [66] worked on the wound healing properties of GH and developed a honey hydrogel dressing for the enhancement of wound healing. The in vivo assessment showed that GH significantly stimulated wound contraction. Microscopic evaluations demonstrated a significant accelerated dermal repair in GH-treated wound, with an early attenuation of inflammatory reaction and reparative activities. A hydrogel with $6 \%$ honey was characterized by $337.04 \%$ elongation, tensile strength of $0.02647 \mathrm{mPa}$, $\mathrm{pH}$ of 4.3 , and golden yellow color was formulated at the end of study as a wound dressing with healing properties. Efficacy of GH in wound healing was also evaluated by 
Tan et al. [67]. Intrasite gel containing modified carboxymethyl cellulose polymer, propylene glycol, and water was used as positive control, whereas saline was used as negative control. The results revealed that treatment with GH and Intrasite gel showed no significant difference in duration of wound healing; both healed in about 13 days as compared to around 16 days in the untreated group. Macroscopic examinations showed the changes in the GH-treated group from moist scab on day 5 , detachment of scab in day 10, to fewer scars in day 15 of treatment. Meanwhile, the histological sections demonstrated new epidermis formed in GH-treated wounds was thinner and covered the entire wound area, providing protection to the wound from further injuries. The Intrasite gel-treated wounds had a faster epithelial regeneration, but the scab on the surface was thicker than that of $\mathrm{GH}$-treated wounds. Wound contraction was also measured by the authors, indicating that GH increased the wound contraction, and the wound contractions were even greater than that of Intrasite gel-treated wound in day 10. The stimulation of GH in wound healing is achieved by providing energy for contractile activity, and enhancing the deposition of fibroblast and collagen, thus decreasing the scar deposition [60,68]. Fibroblasts play a vital role in tissue repair processes [69]. For this reason, a recent study was conducted by Aljadi et al. [70] to look into the effects of $\mathrm{GH}$ and its main constituents on the proliferation of cultured fibroblasts. The strongest effect of GH was noted at $6 \mathrm{~h}$ after treatment and a dose of $1.95 \mathrm{mg} / \mathrm{mL}$, in which a $35 \%$ increase in cell viability over the control $(p<0.0001)$ was observed. The highest stimulatory effect of honey sugar was achieved at $132 \mathrm{mg} / \mathrm{mL}$ for $24 \mathrm{~h}$ with an increase of $16.6 \%$ in cell proliferation over control. Protein extract from honey had no direct effect on the growth of cultured fibroblasts, whilst preformed hydrogen peroxide exerted both stimulatory and inhibitory effects on the growth of cultured fibroblasts. Treatment with $0.57 \mu \mathrm{M}$ preformed $\mathrm{H}_{2} \mathrm{O}_{2}$ for $2 \mathrm{~h}$ showed a significant increase in cell proliferation (11.5\%) over the control $(p<0.05)$, whereas the greatest toxic effect was observed at $57 \mu \mathrm{M}$ preformed $\mathrm{H}_{2} \mathrm{O}_{2}$ for $24 \mathrm{~h}$. Similarly, continuous $\mathrm{H}_{2} \mathrm{O}_{2}$ generated by honey extract mixture (EM) constituted by sugar, protein extract, and phenolic extract could either stimulate or inhibit the growth of fibroblast in vitro. The $0.15 \mathrm{mg} / \mathrm{mL}$ treatment of EM showed the highest stimulatory effect on fibroblast proliferation at $2 \mathrm{~h}$, where a $14.1 \%$ increase in cell growth was observed over the control. At $15 \mathrm{mg} / \mathrm{mL}$ of EM, the highest inhibitory effect was shown at $24 \mathrm{~h}$ with $22 \%$ of reduction in cell viability compared to that of control.

Rozaini et al. [71] observed the efficacy of honey hydrogel dressing with the incorporation of $6 \%$ GH on deep partial-thickness burns in terms of gross appearances, rate of wound contraction, and histological changes. The results demonstrated that wounds treated with honey hydrogel dressing had a better appearance and a significant enhancement in the rate of wound contraction $(p<0.05)$ as compared to the control group at 21 days after burn. Honey hydrogel also conferred a faster epithelialization in treated wounds. The authors continued to use the same formulation for further analysis on the wound healing effects of honey hydrogel using a molecular approach in another study [72]. RT-PCR revealed that the honey hydrogel treatment significantly $(p<0.05)$ suppressed the expression of pro-inflammatory mediators (IL- $1 \alpha$, IL-1 $\beta$, and IL-6).

\section{Other Health Benefits of GH}

In an animal model, Samat et al. [73] observed the effects of GH acute administration on biochemical parameters. Rats fed with $2000 \mathrm{mg} / \mathrm{kg}$ body weight of GH did not show any adverse effects or deaths. The study reported a decrease in weight gain and energy efficiency, but a significant $(p<0.05)$ increase in total food intake and calories in female rats fed with GH when compared to control. In male rats fed with $\mathrm{GH}$, a significant increase in body weight was observed. A significant $(p<0.05)$ decrease in triglycerides was displayed in both male and female rats fed with GH as compared to control. The results suggested the potential of GH in controlling weight gain and triglycerides. To study the effects of GH on the male reproductive system, Asiyah et al. [74] observed the changes of testis parameters and sperm quality in juvenile rats following a 60-day GH supplementation $(1.0 \mathrm{~mL} / 100 \mathrm{~g}$ body weight daily). The results showed that the GH-treated group has significantly $(p<0.05)$ higher sperm motility $\left(18.85 \times 10^{5} / \mathrm{mL}\right)$ and number of normal sperm morphology (193.73) than control group. Meanwhile, the testicular parameters (weight, length, and width) showed no significant changes. 


\section{Conclusions}

Being a natural food, honey is highly appreciated in different cultures. The characterization of the health benefits of honey has confirmed the potential of this natural food as medicine. From the evidence presented in this paper, GH has apparently demonstrated a wide spectrum of biological properties, suggesting its feasibility in clinical applications. However, the clinical intervention studies are still lacking at this stage. A great deal of scientific effort is expected in GH research in order to provide some convincing evidence to support the sustainable use of honey through human trials. Determination of appropriate dosage of GH should be prompted to avoid undesirable side effects. The mechanisms of honey and its active constituents on disease management are still inconclusive; urgency to call for in-depth research ought to be an immediate action. Since phenolic compounds are one of the most interesting groups of chemical compounds studied in honey, future studies should also emphasize the role of this group of active constituents in biological activities. Chemometric methods are required to characterize a complex profile of polyphenols in $\mathrm{GH}$, and isolated compounds should be tested for their possible health benefits.

Acknowledgements: The authors would like to express their sincerest gratitude to financial support from UKM GUP-2014-056 grant on honey research.

Conflicts of Interest: The authors declare no conflict of interest.

\section{References}

1. Othman, N.H. Honey and cancer: Sustainable inverse relationship particularly for developing nations-A review. Evid. Based Complement. Altern. Med. 2012, 2012, 410406. [CrossRef] [PubMed]

2. Gupta, S.S.; Singh, O.; Bhagel, P.S.; Moses, S.; Shukla, S.; Mathur, R.K. Honey dressing versus silver sulfadiazene dressing for wound healing in burn patients: A retrospective study. J. Cutan. Aesthet. Surg. 2011, 4, 183. [CrossRef] [PubMed]

3. Erejuwa, O.O.; Sulaiman, S.A.; Wahab, M.S. Honey: A Novel Antioxidant. Molecules 2012, 17, 4400-4423. [CrossRef] [PubMed]

4. Erejuwa, O.O.; Sulaiman, S.A.; Wahab, M.S.; Sirajudeen, K.N.; Salleh, M.S.; Gurtu, S. Antioxidant protection of Malaysian tualang honey in pancreas of normal and streptozotocin-induced diabetic rats. Ann. Endocrinol. 2010, 71, 291-296. [CrossRef] [PubMed]

5. Erejuwa, O.O.; Gurtu, S.; Sulaiman, S.A.; Wahab, M.S.A.; Sirajudeen, K.N.S.; Salleh, M.S.M. Hypoglycemic and antioxidant effects of honey supplementation in streptozotocin-induced diabetic rats. Int. J. Vitam. Nutr. Res. 2010, 80, 74. [PubMed]

6. Erejuwa, O.O.; Sulaiman, S.A.; Wahab, M.S.A.; Sirajudeen, K.N.S.; Salleh, M.S.M.; Gurtu, S. Antioxidant protective effect of glibenclamide and metformin in combination with honey in pancreas of streptozotocin-induced diabetic rats. Int. J. Mol. Sci. 2010, 11, 2056-2066. [CrossRef] [PubMed]

7. Sherlock, O.; Dolan, A.; Athman, R.; Power, A.; Gethin, G.; Cowman, S.; Humphreys, H. Comparison of the antimicrobial activity of Ulmo honey from Chile and Manuka honey against methicillin-resistant Staphylococcus aureus, Escherichia coli and Pseudomonas aeruginosa. BMC Complement. Altern. Med. 2010, 10, 47. [CrossRef] [PubMed]

8. Swellam, T.; Miyanaga, N.; Onozawa, M.; Hattori, K.; Kawai, K.; Shimazui, T.; Akaza, H. Antineoplastic activity of honey in an experimental bladder cancer implantation model: In vivo and in vitro studies. Int. J. Urol. 2003, 10, 213-219. [CrossRef] [PubMed]

9. Ghashm, A.A.; Othman, N.H.; Khattak, M.N.; Ismail, N.M.; Saini, R. Antiproliferative effect of Tualang honey on oral squamous cell carcinoma and osteosarcoma cell lines. BMC Complemet. Altern. Med. 2010, 10, 49.

10. Inoue, K.; Murayama, S.; Seshimo, F.; Takeba, K.; Yoshimura, Y.; Nakazawa, H. Identification of phenolic compound in manuka honey as specific superoxide anion radical scavenger using electron spin resonance (ESR) and liquid chromatography with coulometric array detection. J. Sci. Food. Agric. 2005, 85, 872-878. [CrossRef]

11. Hamid, K.A.; Mohd, A.F.; MohdZohdi, R.; Eshak, Z.; Omar, R. Pollen analysis of selected Malaysian honey. Acad. J. Entomol. 2015, 8, 99-103. 
12. Moniruzzaman, M.; Sulaiman, S.A.; Khalil, M.I.; Gan, S.H. Evaluation of physicochemical and antioxidant properties of sourwood and other Malaysian honeys: A comparison with manuka honey. Chem. Cent. J. 2013, 7, 138. [CrossRef] [PubMed]

13. Khalil, M.I.; Mahaneem, M.; Jamalullail, S.M.S.; Alam, N.; Sulaiman, S.A. Evaluation of radical scavenging activity and colour intensity of nine Malaysian honeys of different origin. JAAS 2011, 3, 4-11. [CrossRef]

14. Khalil, M.I.; Sulaiman, S.A.; Gan, S.H. High 5-hydroxymethylfurfural concentrations are found in Malaysian honey samples stored for more than one year. Food Chem. Toxicol. 2010, 48, 2388-2392. [CrossRef] [PubMed]

15. Hussein, S.Z.; Yusoff, K.M.; Makpol, S.; Mohd, Y.Y. Does gamma irradiation affect physicochemical properties of honey? Clin. Ther. 2014, 165, e125.

16. Bogdanov, S. Book of honey: Honey composition. Bee Prod. Sci. 2009, 1-9. Available online: http:/ / fantasticflavour.com/yahoo_site_admin/assets/docs/CompositionHoney.20105942.pdf (accessed on 15 December 2015).

17. Alimentarius Commission. Revised codex standard for honey. Codex Stan 2001, 12, 1982.

18. Bogdanov, S.; Jurendic, T.; Sieber, R.; Gallmann, P. Honey for nutrition and health: A review. J. Am. Coll. Nutr. 2008, 27, 677-689. [CrossRef] [PubMed]

19. Moniruzzaman, M.; Chowdhury, M.A.Z.; Rahman, M.A.; Sulaiman, S.A.; Gan, S.H. Determination of Mineral, Trace Element, and Pesticide Levels in Honey Samples Originating from Different Regions of Malaysia Compared to Manuka Honey. Bio Med. Res. Int. 2014, 2014, 359890. [CrossRef] [PubMed]

20. Chua, L.S.; Rahaman, N.L.A.; Adnan, N.A.; Eddie Tan, T.T. Antioxidant activity of three honey samples in relation with their biochemical components. J. Anal. Methods Chem. 2013, 2013. [CrossRef] [PubMed]

21. Chua, L.S.; Adnan, N.A.; Abdul-Rahaman, N.L.; Sarmidi, M.R. Effect of thermal treatment on the biochemical composition of tropical honey samples. Int. Food Res. J. 2014, 21, 773-778.

22. Hussein, S.Z.; Yusoff, K.M.; Makpol, S.; Yusof, Y.A.M. Antioxidant capacities and total phenolic contents increase with gamma irradiation in two types of Malaysian honey. Molecules 2011, 16, 6378-6395. [CrossRef] [PubMed]

23. Kishore, R.K.; Halim, A.S.; Syazana, M.N.; Sirajudeen, K.N.S. Tualang honey has higher phenolic content and greater radical scavenging activity compared with other honey sources. Nutr. Res. 2011, 31, 322-325.

24. Ginter, E. The role of antioxidants in the prevention of tumors. Bratisl Lek Listy 1995, 96, 195-209. [PubMed]

25. Hertog, M.G.; Feskens, E.J.; Kromhout, D.; Hollman, P.C.H.; Katan, M.B. Dietary antioxidant flavonoids and risk of coronary heart disease: The Zutphen Elderly Study. Lancet 1993, 342, 1007-1011. [CrossRef]

26. Wana, A. Oxygen free radicals impair wound healing in ischemic rats. Ann. Plast. Surg. 1997, 39, 516-523.

27. Smirnov, D.A. Acute pancreatitis and biological antioxidants. Khirurgiia 1994, 3, 30-32. [PubMed]

28. Aljadi, A.M.; Kamaruddin, M.Y. Evaluation of the phenolic contents and antioxidant capacities of two Malaysian floral honeys. Food Chem. 2004, 85, 513-518. [CrossRef]

29. Khalil, M.I.; Alam, N.; Moniruzzaman, M.; Sulaiman, S.A.; Gan, S.H. Phenolic acid composition and antioxidant properties of Malaysian honeys. J. Food Sci. 2011, 76, C921-C928. [CrossRef] [PubMed]

30. Yao, L.K.; Razak, S.L.A.; Ismail, N.; Fai, N.C.; Asgar, M.H.A.M.; Sharif, N.M.; Aan, G.J.; Jubri, Z. Malaysian gelam honey reduces oxidative damage and modulates antioxidant enzyme activities in young and middle aged rats. J. Med. Plant Res. 2011, 5, 5618-5625.

31. Makpol, S.; Ahmad, T.A.F.T.; Jubri, Z.; Rejab, N.; Yusof, N.; Yusof, Y.A.M. Gelam honey acting as a radioprotectant agent in gamma-irradiated human diploid fibroblasts. J. Med. Plants Res. 2012, 6, $129-138$.

32. Sahhugi, Z.; Hasenan, S.M.; Jubri, Z. Protective effects of gelam honey against oxidative damage in young and aged rats. Oxid. Med. Cell. Longev. 2014, 2014, 673628. [CrossRef] [PubMed]

33. Batumalaie, K.; Qvist, R.; Yusof, K.M.; Ismail, I.S.; Sekaran, S.D. The antioxidant effect of the Malaysian Gelam honey on pancreatic hamster cells cultured under hyperglycemic conditions. Clin. Exp. Med. 2014, 14, 185-195. [CrossRef] [PubMed]

34. Ferrero-Miliani, L.; Nielsen, O.H.; Andersen, P.S.; Girardin, S.E. Chronic inflammation: Importance of NOD2 and NALP3 in interleukin-1 beta generation. Clin. Exp. Immunol. 2007, 147, 227-235. [CrossRef] [PubMed]

35. Lawrencem, T.; Fong, C. The resolution of inflammation: Anti-inflammatory roles for NF-кB. Int. J. Biochem. Cell Biol. 2010, 42, 519-523. [CrossRef] [PubMed]

36. Iwalewa, E.O.; McGaw, L.J.; Naidoo, V.; Eloff, J.N. Inflammation: The foundation of diseases and disorders. A review of phytomedicines of South African origin used to treat pain and inflammatory conditions. Afr. J. Biotechnol. 2007, 6, 2868-2885. 
37. Mueller, M.; Hobiger, S.; Jungbauer, A. Anti-inflammatory activity of extracts from fruits, herbs and spices. Food Chem. 2010, 122, 987-996. [CrossRef]

38. Hung, T.M.; Dang, N.H.; Kim, J.C.; Choi, J.S.; Lee, H.K.; Min, B.S. Phenolicglycosides from Alangiumsalviifolium leaves with inhibitory activity on LPS-inducedNO, PGE2 and TNF- $\alpha$ production. Bioorg. Med. Chem. Lett. 2009, 19, 4389-4393. [CrossRef] [PubMed]

39. Calixto, J.B.; Campos, M.M.; Otuki, M.F.; Santos, A.R.S. Anti-inflammatory compounds of plant origin. Part II Modulation of pro-inflammatory cytokines, chemokines and adhesion molecules. Planta Med. 2004, 70, 93-103. [PubMed]

40. Reyes-Gordillo, K.; Segovia, J.; Shibayama, M.; Vergara, P.; Moreno, M.G.; Muriel, P. Curcumin protects against acute liver damage in the rat by inhibiting NFkB, proinflammatory cytokines and oxidative stress. Biochim. Biophys. Acta 2007, 1770, 989-996. [CrossRef] [PubMed]

41. Himaya, S.W.A.; Ryu, B.; Qian, Z.J.; Li, Y.; Kim, S.K. 1-(5-bromo-2-hydroxy-4-methoxyphenyl)ethanone [SE1] suppresses pro-inflammatory responses by blocking NF-kB and MAPK signaling pathways in activated microglia. Eur. J. Pharmacol. 2001, 670, 608-616. [CrossRef] [PubMed]

42. Kassim, M.; Achoui, M.; Mansor, M.; Yusoff, K.M. The inhibitory effects of Gelam honey and its extracts on nitric oxide and prostaglandin E2 in inflammatory tissues. Fitoterapia 2010, 81, 1196-1201. [CrossRef] [PubMed]

43. Hussein, S.Z.; MohdYusoff, K.; Makpol, S.; MohdYusof, Y.A. Gelam Honey Inhibits the Production of Proinflammatory, Mediators NO, PGE2, TNF- $\alpha$, and IL-6 in Carrageenan-Induced Acute Paw Edema in Rats. Evid. Based Complement. Altern. Med. 2012, 2012, 109636. [CrossRef] [PubMed]

44. Hussein, S.Z.; MohdYusoff, K.; Makpol, S.; MohdYusof, Y.A. Gelam honey attenuates carrageenan-induced rat paw inflammation via NF-kB pathway. PLoS ONE 2013, 8, 0072365. [CrossRef] [PubMed]

45. Kassim, M.; Yusoff, K.M.; Ong, G.; Sekaran, S.; Yusof, M.Y.B.M.; Mansor, M. Gelam honey inhibits lipopolysaccharide-induced endotoxemia in rats through the induction of heme oxygenase-1 and the inhibition of cytokines, nitric oxide, and high-mobility group protein B1. Fitoterapia 2012, 83, 1054-1059. [CrossRef] [PubMed]

46. Aziz, S.A.; Hamzah, N.; Fauzi, A.R.; Yusof, Y.A.M.; Ibrahim, N.; Abdul Rahman, M.; AbdulGhafar, N.; Baharin, B. The Effect of Gelam (Melaleuca cajuputi) Honey on Inflammatory Mediators in PeriodontitisInduced Sprague-Dawley Rats. Int. J. Appl. Res. Nat. Prod. 2014, 7, 7-16.

47. White, J.W.; Subers, M.H.; Schepartz, A.I. Theidentification of inhibine, the antibacterial factor in honey, as hydrogen peroxide and its origin in a honey glucose-oxidase system. Biochim. Biophys. Acta 1963, 73, 57-70. [CrossRef]

48. Jaganathan, S.K.; Mandal, M. Antiproliferative effects of honey and of its polyphenols: A review. J. Biomed. Biotechnol. 2009, 2009. Available online: http://www.hindawi.com/journals/jbb/2009/830616 (accessed on 20 December 2015). [CrossRef] [PubMed]

49. Mandal, M.D.; Mandal, S. Honey: Its medicinal property and antibacterial activity. Asian Pac. J. Trop. Biomed. 2011, 1, 154-160. Available online: http://apjtb.com/zz/April/16.pdf (accessed on 21 December 2015). [CrossRef]

50. Zainol, M.I.; Yusoff, K.M.; Yusof, M.Y.M. Antibacterial activity of selected Malaysian honey. BMC Complement. Altern. Med. 2013, 13, 129. [CrossRef] [PubMed]

51. Ng, W.J.; Ken, K.W.; Kumar, R.V.; Gunasagaran, H.; Chandramogan, V.; Lee, Y.Y. In-Vitro Screening Of Malaysian Honey From Different Floral Sources For Antibacterial Activity On Human Pathogenic Bacteria. Afr. J. Tradit. Complement. Altern. Med. 2014, 11, 315-318. [CrossRef] [PubMed]

52. Ng, W.J.; Lim, K.Y.; Chong, J.Y.; Low, K.L. In vitro Screening of Honey against Enterococcus spp. Biofilm. J. Med. Bioeng. 2014, 3, 23-28. [CrossRef]

53. Tendolkar, P.M.; Baghdayan, A.S.; Gilmore, M.S.; Shankar, N. Enterococcal surface protein, Esp, enhances biofilm formation by Enterococcus faecalis. Infect. Immun. 2004, 72, 6032-6039. [CrossRef] [PubMed]

54. Aljadi, A.M.; Yusoff, K.M. Isolation and identification of phenolic acids in Malaysian honey with antibacterial properties. Turk. J. Med. Sci. 2003, 33, 229-236.

55. Jubri, Z.; Narayanan, N.N.N.; Karim, N.A.; Ngah, W.Z.W. Antiproliferative activity and apoptosis induction by gelam honey on liver cancer cell line. Int. J. Appl. 2012, 2, 135-141. 
56. Wen, C.T.P.; Hussein, S.Z.; Abdullah, S.; Karim, N.A.; Makpol, S.; Yusof, Y.A.M. Gelam and nenas honeys inhibit proliferation of HT 29 colon cancer cells by inducing DNA damage and apoptosis while suppressing inflammation. Asian Pac. J. Cancer Prev. 2012, 13, 1605-1610. [CrossRef] [PubMed]

57. Abu, M.N.; Salleh, M.A.M.; Eshak, Z.; Hasan, M.H.; Hassan, H.F.; Ismail, W.I.W. Anti-proliferative effect of Tinasporacrispa (L.) Hook. F. \& Thompson and Gelam (Melaleuca sp.) honey on several cancer cell lines. In Proceedings of the IEEE Symposium on Business, Engineering and Industrial Applications (ISBEIA), Langkawi, Malaysia, 25-28 September 2011; pp. 545-548.

58. Tahir, A.A.; Sani, N.F.A.; Murad, N.A.; Makpol, S.; Ngah, W.Z.W.; Yusof, Y.A.M. Combined ginger extract \& Gelam honey modulate Ras/ERK and PI3K/AKT pathway genes in colon cancer HT29 cells. Nutr. J. 2015, 14, 31. [PubMed]

59. Wee, L.H.; Morad, N.A.; Aan, G.J.; Makpol, S.; Ngah, W.Z.W.; Yusof, Y.A.M. Mechanism of chemoprevention against colon cancer cells using combined Gelam honey and Ginger extract via mTOR and Wnt/ $\beta$-catenin pathways. Asian Pac. J. Cancer Prev. 2015, 16, 6549-6556. [CrossRef] [PubMed]

60. Aljadi, A.M.; Kamaruddin, M.Y.; Jamal, A.M.; MohdYassim, M.Y. Biochemical study on the efficacy of Malaysian honey on inflicted wounds: An animal model. Med. J. Islam. Acad. Sci. 2000, 13, 125-132.

61. Salmah, I.; Mahmood, A.A.; Sidik, K. Synergistic effects of alcoholic extract of sweetbasil (Ocimumbasilicum L.) leaves and honey on cutaneous wound healing in rats. Int. J. Mol. Med. Adv. Sci. 2005, 1, 220-224.

62. Suguna, L.; Chandrakasan, G.; Thomas Joseph, K. Influence of honey on collagenmetabolism during wound healing in rats. J. Clin. Biochem. Nutr. 1992, 13, 7-12. [CrossRef]

63. Rozaini, M.Z.; Zuki, A.; Noordin, M.; Norimah, Y.; Hakim, A.N. Tensile Strength Evaluation on Burns Wound Healing Treated With Nenas (Ananascomosus spp.) and Gelam (Melaleuca spp.) Honey. In Proceedings of the 11th International Conference of The Association of Institutions for Tropical Veterinary Medicine, Petaling Jaya, Malaysia, 23-27 August 2004; p. 338.

64. Rozaini, M.Z.; Zuki, A.B.Z.; Noordin, M.; Norimah, Y.; Hakim, A.N. Histological Evaluation on Burns Wound Healing Treated with Nenas (Ananascomosus spp.) and Gelam (Melaleuca spp.) Honey. In Proceedings of the 11th International Conference of The Association of Institutions for Tropical Veterinary Medicine, Petaling Jaya, Malaysia, 23-27 August 2004; p. 381.

65. Rozaini, M.Z.; Zuki, A.B.Z.; Noordin, M.M.; Norimah, Y.; Nazrul Hakim, A. Macroscopic evaluation of burn wounds healing progress treated with different types of honey. Pak. J. Biol. Sci. 2005, 8, 672-678.

66. Yusof, N.; Hafiza, A.A.; Zohdi, R.M.; Bakar, M.Z.A. Development of honey hydrogel dressing for enhanced wound healing. Radiat. Phys. Chem. 2007, 76, 1767-1770. [CrossRef]

67. Tan, M.K.; HasanAdli, D.S.; Tumiran, M.A.; Abdulla, M.A.; Yusoff, K.M. The efficacy of Gelam honey dressing towards excisional wound healing. Evid. Based Complement. Altern. Med. 2012, 2012, 805932.

68. Medhi, B.; Puri, A.; Upadhyay, S.; Kaman, L. Topical application of honey in the treatment of wound healing: A meta-analysis. JK Sci. 2008, 10, 166-169.

69. Raf, C. Wound Repair: Overview and General Considerations. In The Molecular and Cellular Biology of Wound Repair, 2nd ed.; Raf, C., Ed.; Plenumpress: New York, NY, USA, 1996; pp. 3-50.

70. Al-jadi, A.M.; Enchang, F.K.; Yusoff, K.M. The effect of Malaysian honey and its major components on the proliferation of cultured fibroblasts. Turk. J. Med. Sci. 2014, 44, 733-740. [CrossRef] [PubMed]

71. Rozaini, M.Z.; Md. Zuki, A.B.Z.; Norimah, Y.; Noordin, M.M.; Muhammad Nazrul, H.S.; Asnah, H. Honey hydrogel dressing to treat burn wound in rats-a preliminary report. Pertan. J. Trop. Agric. Sci. 2012, 35, 67-74.

72. Rozaini, M.Z.; Zuki, A.B.Z.; Norimah, Y.; Noordin, M.M.; Muhammad Nazrul, H.A. Gelam (Melaleuca spp.) honey-based hydrogel as burn wound dressing. Evid. Based Complement. Altern. Med. 2012, 2012, 843025.

73. Samat, S.; Nor, N.A.M.; Hussein, F.N.; Ismail, W.I.W. Effects of Gelam and Acacia honey acute administration on some biochemical parameters of Sprague Dawley rats. BMC Complement. Altern. Med. 2014, 14, 146. [CrossRef] [PubMed]

74. Asiyah, H.A.; Syazana, N.S.; Hashida, N.H.; DurriyyahSharifah, H.A.; Kamaruddin, M.Y. Effects of nicotine and Gelam honey on testis parameters and sperm qualities of juvenile rats. Sci. Res. Essays 2011, 6, 5471-5474. [CrossRef]

(C) 2016 by the authors; licensee MDPI, Basel, Switzerland. This article is an open access article distributed under the terms and conditions of the Creative Commons by Attribution (CC-BY) license (http://creativecommons.org/licenses/by/4.0/). 